\title{
Pengaruh Pendekatan Konflik Kognitif Terhadap Kemampuan Berpikir Kritis Pada Materi Gerak Lurus
}

\author{
${ }^{1}$ Sutrio, ${ }^{2}$ Muh. Makhrus, ${ }^{3}$ Armi Larasati \\ ${ }^{1,2,3}$ Program Studi Pendidikan Fisika, Fakultas Keguruan dan Ilmu Pendidikan, Universitas \\ Mataram, Jl. Majapahit 62 Mataram, Indonesia 83125
}

\section{Email Korespondensi: makhrus.fkip@unram.ac.id}

\begin{tabular}{|c|c|}
\hline & \\
\hline $\begin{array}{l}\text { Revlse } \\
\text { Publis }\end{array}$ & \multirow{2}{*}{$\begin{array}{l}\text { This study aims to determine the effect of the cognitive conflict approach on the } \\
\text { critical thinking skills of senior high school students in grade X on straight } \\
\text { motion material. This type of research is a pre-experimental research design } \\
\text { with One Group Pretest-Posttest Design. The population in this study were all } \\
\text { students of class X MIPA SMAN } 1 \text { Narmada. The research sample was } \\
\text { obtained using a purposive sampling technique, obtained class X MIPA } 1 \text { as } \\
\text { experimental class } 1 \text {, class X MIPA } 2 \text { as experimental class 2, and class X } \\
\text { MIPA } 3 \text { as experimental class } 3 \text {. Data collection on critical thinking skills used } \\
\text { essay test as many as } 5 \text { questions. Hypothesis test analysis used a statistical } \\
\text { paired sample t-test and showed that Ho was rejected and Ha was accepted. } \\
\text { This shows that the cognitive conflict approach affects the critical thinking } \\
\text { skills of students in straight motion material. This approach can be an } \\
\text { alternative solution for various methods/models/approaches in learning } \\
\text { physics. }\end{array}$} \\
\hline $\begin{array}{l}\boldsymbol{K} \\
C \\
a p \\
s k \\
m\end{array}$ & \\
\hline Info & AOSS \\
\hline & \multirow{2}{*}{$\begin{array}{l}\text { Penelitian ini bertujuan untuk mengetahui pengaruh pendekatan konflik } \\
\text { kognitif terhadap kemampuan berpikir kritis peserta didik SMA kelas X pada } \\
\text { materi gerak lurus. Jenis penelitian ini adalah Pre-experimental dengan desain } \\
\text { penelitian One Group Pretest-Posttest Design. Populasi pada penelitian ini } \\
\text { adalah seluruh peserta didik kelas X MIPA SMAN } 1 \text { Narmada. Sampel } \\
\text { penelitian diperoleh menggunakan teknik purposive sampling, diperoleh kelas } \\
\text { X MIPA } 1 \text { sebagai kelas eksperimen 1, kelas X MIPA } 2 \text { sebagai kelas } \\
\text { eksperimen } 2 \text {, dan kelas X MIPA } 3 \text { sebagai kelas eksperimen } 3 \text {. Pengumpulan } \\
\text { data kemampuan berpikir kritis menggunakan tes uraian sebanyak } 5 \text { soal. } \\
\text { Analisis uji hipotesis menggunakan uji statistik paired sample t-test dan } \\
\text { menujukkan bahwa } \mathrm{H}_{\mathrm{O}} \text { ditolak dan } \mathrm{H}_{\mathrm{a}} \text { diterima. Hal ini menunjukkan bahwa } \\
\text { pendekatan konflik kognitif berpengaruh terhadap kemampuan berpikir kritis } \\
\text { peerta didik pada materi gerak lurus. Pendekatan ini bisa menjadi alternatif } \\
\text { solusi untuk variasi metode/model/pendekatan dalam pembelajaran fisika. }\end{array}$} \\
\hline & \\
\hline
\end{tabular}

Sitasi: Sutrio, S., Makhrus, M., Larasati, A. (2020). Pengaruh Pendekatan Konflik Kognitif terhadap Kemampuan Berpikir Kritis Pada Materi Gerak Lurus. Kappa Journal, 4(2), 136-142.

\section{PENDAHULUAN}

Proses pembelajaran fisika di sekolah, umumnya belum mengarah pada usaha peserta didik untuk mengembangkan kemampuan berpikir. Pembelajaran fisika yang dilaksanakan seharusnya mengarahkan peserta didik untuk mencari tahu konsep-konsep fisika sehingga keterampilan berpikir peserta didik dapat terbentuk (Nasution, 2018). Peserta didik juga cenderung hanya menghafal konsep dan kurang mampu menghubungkan antara apa yang dipelajari dan bagaimana konsep tersebut diaplikasikan. Peserta didik beranggapan pelajaran 
fisika yang dipelajari tidak memiliki keterkaitan dengan kehidupan nyata dan terlalu banyak rumus yang rumit (Hidayatullah, Makhrus, \& Gunada, 2018). Hal ini terjadi karena pembelajaran yang mereka alami tidak mampu menghubungkan konsep yang mereka miliki dengan konsep baru dan dengan lingkungannya. Akibatnya kemampuan berpikir peserta didik tidak dapat meningkat. Berdasarkan hal itu, diperlukan inovasi pembelajaran yang memperhatikan kemampuan berpikir peserta didik untuk menemukan sendiri konsepnya berdasarkan pengalaman belajar yang dimilikinya.

Salah satu kemampuan berpikir yang saat penting adalah kemampuan berpikir kritis. Kemampuan berpikir kritis adalah kemampuan berpikir peserta didik untuk mengembangkan dua atau lebih informasi untuk memperoleh pengetahuan (Setyowati, Subali, \& Mosik, 2011). Berpikir kritis merupakan kemampuan keterampilan berpikir yang kompleks yang terdiri dari menganalisis, mengidentifikasi, memilih, mengevaluasi, memberi kesimpulan yang tepat (Usmeldi, Amini, \& Trisna, 2017). Peserta didik yang memiliki kemampuan berpikir kritis yang baik akan mampu mengambil tindakan ataupun kesimpulan yang tepat. Kemampuan berpikir kritis ini termasuk dalam kemampuan abad 21 yang diharapkan dimiliki oleh peserta didik untuk menghadapi tantangan di era ini (Priyadi, Mustajab, Tatsar, \& Kusairi, 2018).

Guru sebagai agen pembelajaran memerlukan pendekatan yang dapat mengkontruksi pengetahuan peserta didik sehingga dapat meningkatkan kemampuan berpikir kritis fisika peserta didik. Perbaikan dan inovasi dalam kegiatan pembelajaran perlu dilakukan untuk mengatasi masalah yang terjadi selama kegiatan untuk meningkatkan hasil belajar fisika peserta didik. Pemilihan pendekatan, model, dan metode pembelajaran yang tepat, penting untuk meningkatkan kemampuan berpikir kritis peserta didik. Salah satu alternatif pemecahan masalalahnya adalah dengan menggunakan pendekatan konflik kognif. Konflik kognitif adalah sebuah keadaan dimana peserta didik merasa adannya ketidakcocokan antara struktur kognitif mereka dengan keadaan lingkungan (Lee, Kwon, Park, Kim, Kwon, \& Park, 2003). Pembelajaran dengan pendekatan konflik kognitif dapat membantu peserta didik membangun pengetahuannya sendiri karena melibatkan peserta didik selama proses pembelajaran yang menghadapkan peserta didik dengan situasi yang bertentangan dengan konsep yang dimiliki, kemudian di arahkan pada percobaan atau demonstrasi untuk membuktikan konsep tersebut (Makhrus, Zuhdi, Wahyudi, \& Taufik, 2020). Pembelajaran dengan konflik kognitif membuat peserta didik mengalami proses asimilasi dan akomodasi sehingga peserta didik membangun pengetahuannya sampai konsep dipahaminnya tidak bertentangan dengan konsep para ilmuan (Makhrus, 2018). Hal Terpenting dalam konflik kognitif adalah menarik perhatian peserta ke dalam keadaan kontradiksi saat proses pembelajaran (Hidayatullah, Jumadi, Nadhiroh, Kartika, Nuha, \& Erlangga, 2020). Perbaikan pembelajaran dengan penggunaan pendekatan konflik kognitif diharapkan mampu meningkatkan kemampuan berpikir kritis peserta didik.

Berdasarkan uraian di atas, peneliti tertarik untuk melakukan penelitian berjudul "Pengaruh Pendekatan Konflik terhadap Kemampuan Berpikir Kritis pada Materi Gerak Lurus". Tujuan penelitian ini yaitu untuk mengetahui pengaruh pendekatan konflik kognitif terhadap kemampuan berpikir kritis pada materi Gerak Lurus.

\section{METODE}

Jenis penelitian yang digunakan adalah pre-experimental dengan desain Only One Group Pretest-Posttest. Populasi dalam penelitian ini adalah seluruh peserta didik kelas X MIPA 
di SMAN 1 Narmada 2018/2019 yang berjumlah 6 kelas. Sampel adalah bagian dari populasi. Sampel yang digunakan dipilih dengan menggunakan teknik purposive sampling. Perlakukan berupa pendekatan konflik kognitif. Ketiga kelompok sampel diberikan tes awal untuk mengukur kondisi awal dan tes akhir untuk mengetahui hasil perlakuan. Desain penelitian ini dapat dilihat dalam Tabel 1.

Tabel 1. Desain Penelitian

\begin{tabular}{cccc}
\hline Kelas & Pre-test & Perlakuan & Post-test \\
\hline Eksperimen & $\mathrm{O}_{1}$ & $\mathrm{X}$ & $\mathrm{O}_{2}$ \\
\hline & & \multicolumn{2}{c}{ (Sugiyono, 2017:75) }
\end{tabular}

Kemampuan berpikir kritis diukur melalui LKPD dan tes uraian berpikir kritis yang sudah di validasi sebanyak 5 soal. Teknik analisis data penelitian ini menggunakan statistik deskriptif untuk menganalisis tingkat kemampuan berpikir kritis saat proses pembelajaran, statistik inferensial paired sample t-test untuk menguji pengaruh pendekatan konflik kognitif terhadap kemampuan berpikir kritis, dan N-Gain untuk melihat peningkatan kemampuan berpikir kritis per indikatornya.

\section{HASIL DAN PEMBAHASAN}

Penelitian ini bertujuan untuk menganalisis tingkat kemampuan berpikir kritis pada saat proses dan hasil pembelajaran dengan pendekatan konflik kognitif. Pendekatan konflik kognitif adalah keadaan di mana peserta didik merasa ada informasi yang kontradiktif yang mempengaruhi gagasan dalam struktur kognitifnya dan karenanya mereka dihadapkan pada situasi baru untuk memecahkan masalah dalam pembelajaran, sehingga tercipta konsep yang baru (Chow \& Treagust, 2013). Tingkatkan kemampuan berpikir kritis peserta didik pada saat pembelajaran diukur melalui LKPD yang dilengkapi soal kemampuan berpikir kritis. Hasil analisis menunjukkan bahwa kemampuan berpikir kritis peserta didik saat proses pembelajaran tergolong kategori tinggi. Hal ini terjadi karena peserta didik memiliki konsepsi yang bermacam-macam dan konsepsi tersebut masih salah. Peserta didik banyak mengalami keadaan kontradiksi antara konsepsinya dengan konsep ilmiah yang disajikan guru saat pembelajaran yang mengakibatkan terjadi perubahan konseptual pada kognitif peserta didik . berdasarkan hal tersebut, maka pendekatan konflik kognitif sangat penting untuk meningkatkan kemampuan berpikir kritis peserta didik. Pendapat ini sesuai dengan hasil penelitian Wiradana (2012) yang menyimpulkan bahwa pendekatan konflik menuntut kemampuan berpikir yang lebih saat proses pemberian konflik untuk merubah konsepsi yang dimiliki peserta didik. Secara detail hasil analisis tingkat kemampuan berpikir kritis pada saat pembelajaran dapat diamati pada Gambar 1 berikut. 


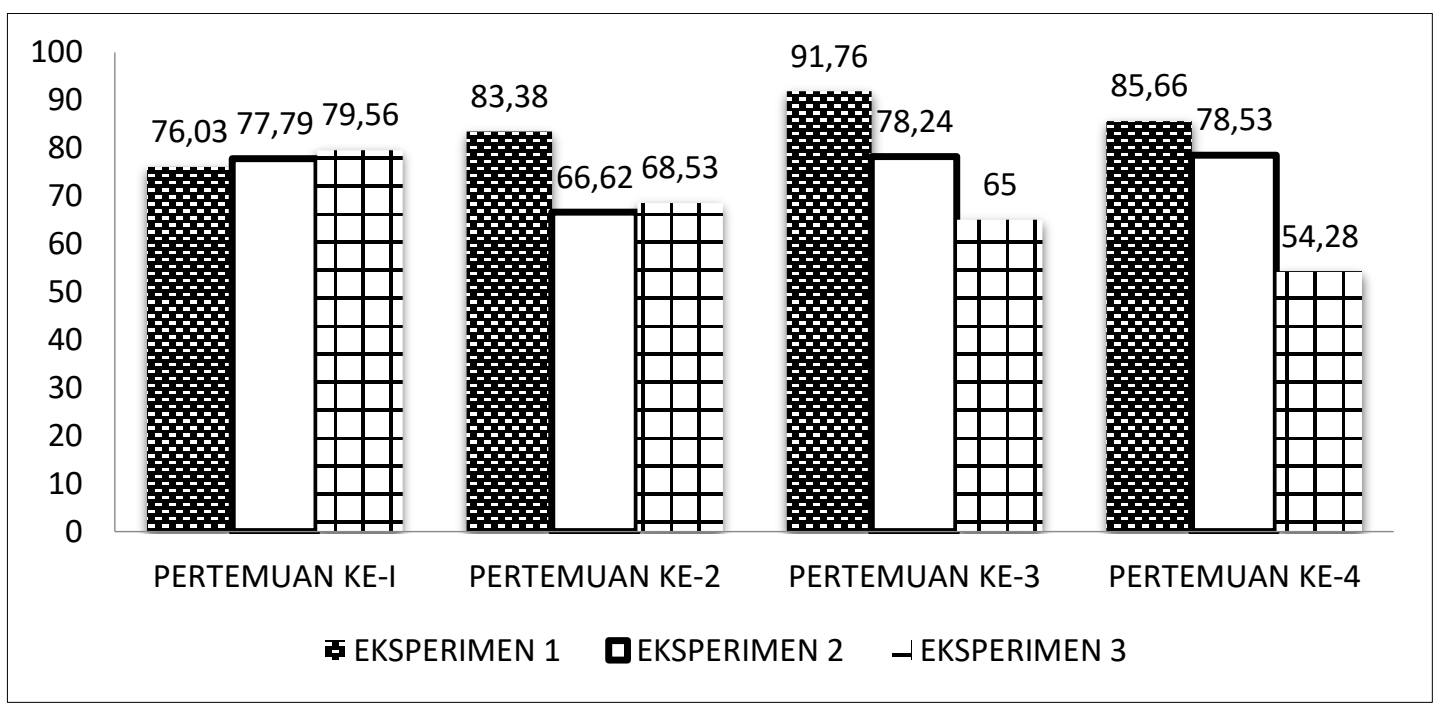

Gambar 1. Tingkat kemampuan berpikir kritis saat proses pembelajaran

Hasil yang didapatkan seperti yang terlihat pada Gambar 1 bahwa peserta didik pada kelas eksperimen 1 memiliki tingkat kemampuan berpikir kritis yang lebih tinggi dibandingkan kelas eksperimen 2 dan eskperimen 3 pada semua sub materi kecuali pada sub materi pertama (GLB), karena kelas eksperimen 1 serius dan sangat memperhatikan guru ketika menjelaskan pelajaran dan ketika mengerjakan LKPD, kelas eksperimen 1 sebagian besar teliti dan aktif dalam menyelesaikan soal yang ada pada LKPD dan selama melakukan percobaan. Pendekatan konflik kognitif menuntut kemampuan berpikir lebih pada saat proses pemberian konflik dalam rangka mengubah miskonsepsi yang dimiliki.

Data kemampuan awal yang digunakan dalam penelitian ini adalah data hasil dari tes awal (pre-test) peserta didik sebelum diberikan perlakuan. Data kemampuan akhir yang diperoleh pada penelitian ini dilakukan pada posttest. Data kemampuan berpikir kritis untuk pretest dan posttest termasuk dalam kategori homogen. Kemampuan berpikir kritis untuk pretest dan posttest memiliki nilai $F_{\text {hitung }}$ masing-masing sebesar 3,31 dan 2,22. Hasil ini apabila dikalkulasikan dengan $\boldsymbol{F}_{\text {tabel }}$ maka diketahui $F_{\text {hitung }}<F_{\text {tabel }}$, sehingga dapat disimpulkan data pretest dan posttest kemampuan berpikir kritis termasuk homogen.

Uji normalitas dilakukan untuk mengetahui data yang digunakan terdistribusi normal atau tidak. Uji normalitas merupakan syarat yang harus terpenuhi sebelum melakukan uji hipotesis. Nilai $\chi_{\text {hitung }}^{2}$ pretest dan posttes kurang dari $\chi_{\text {tabel }}^{2}=11,07$ baik pada pretest dan posttest yang berarti bahwa data terdistribusi normal. Berdarkan hasil uji homogenitas dan normalitas dapat disimpukan bahwa data pretest dan posttest dalam kategori homogen dan normal, sehingga dapat dilanjutkan ke uji hipotesis.

Uji paired sample t test digunakan untuk mengetahui perbedaan nilai rata-rata sebelum perlakuan dan sesudah diberikan perlakuan dengan pendekatan konflik kognitif. Kriteria pengambilan keputusan pada uji $\mathrm{t}$ berpasangan atau paired sample t test ini bisa dilakukan dengan 3 cara yaitu: 1) jika nilai sig. (2-tailed) lebih kecil daripada 0,05, maka $\mathrm{Ha}_{\mathrm{a}}$ diterima dan $\mathrm{H} 0$ ditolak; jika 2) jika $\mathrm{t}_{\text {hitung }}>\mathrm{t}_{\text {tabel }}$ maka $\mathrm{H}_{\mathrm{a}}$ diterima dan $\mathrm{H}_{0}$ ditolak; 3) jika $-\mathrm{t}_{\text {hitung }}<-$ $\mathrm{t}_{\text {tabel}}$, maka $\mathrm{H}_{\mathrm{a}}$ diterima dan $\mathrm{H}_{0}$ ditolak. Rata-rata skor Pre-test pada setiap kelas eksperimen sebelum diterapkan pendekatan konflik kognitif di tiap kelas eksperimen tergolong dalam kategori rendah, seperti ditunjukkan pada Gambar 2 berikut. 


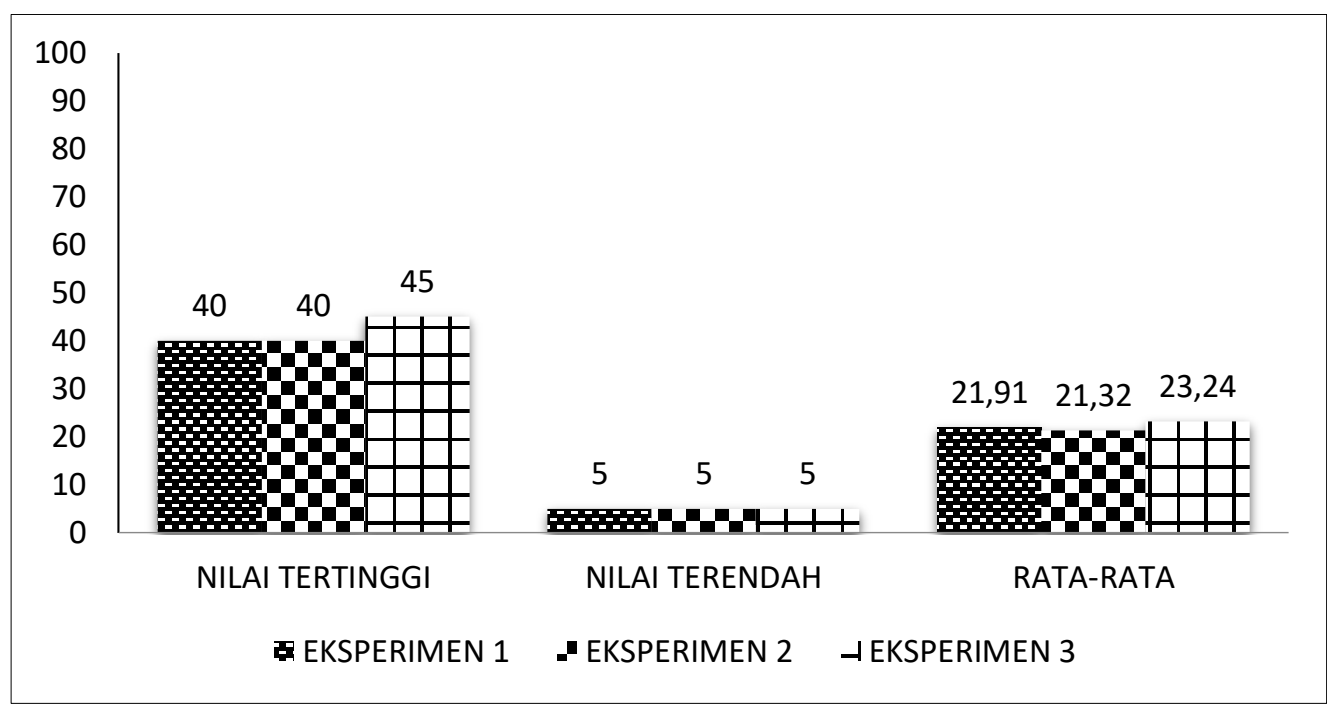

Gambar 2. Perbandingan Hasil Pretest Keterampilan Berpikir Kritis

Berdasarkan hasil analisis data posttest kemampuan berpikir kritis menujukkan bawa setiap kelas eksperimen mengalami peningkatan nilai rata-rata dari pretest yang dapat dilihat pada (Gambar 3). Hal ini menunjukkan ada perbedaan dan peningkatan kemampuan berpikir kritis yang dialami peserta didik setelah melaksanakan pembelajaran dengan pendekatan konflik kognitif.

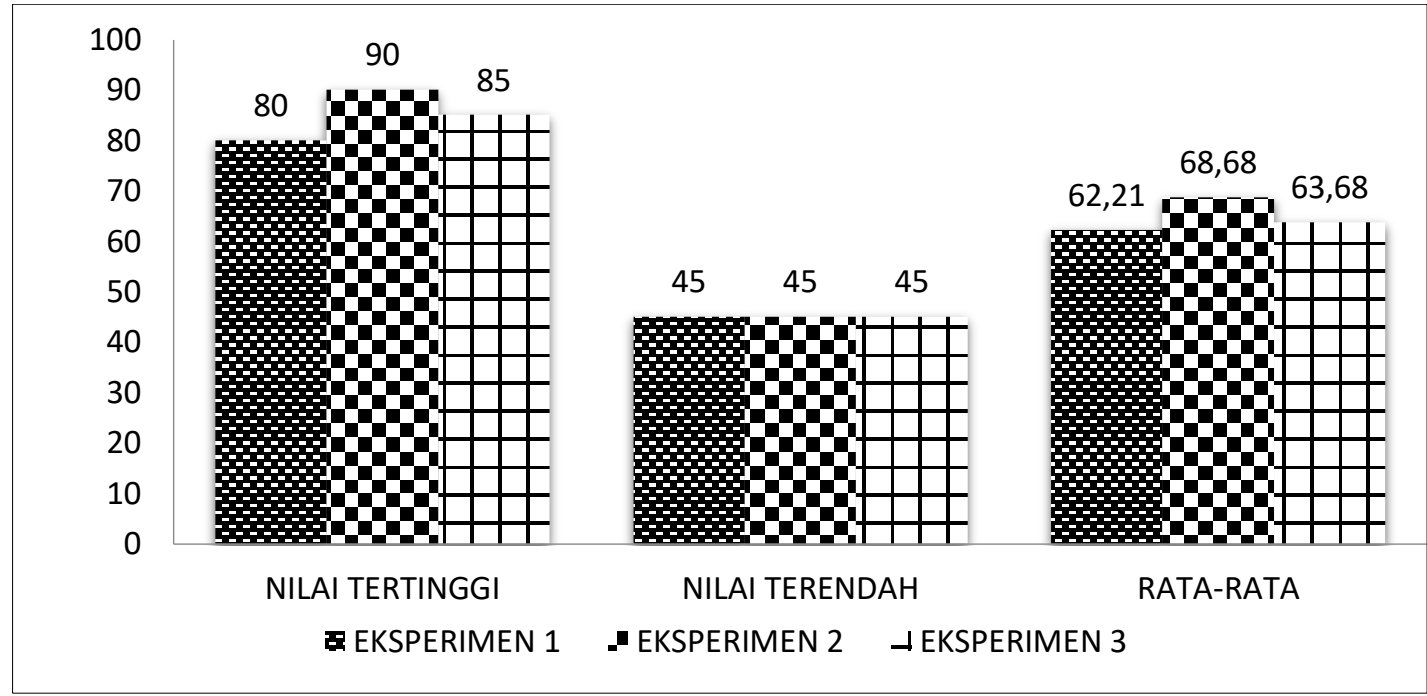

Gambar 3. Perbandingan Hasil Posttest Keterampilan Berpikir Kritis

Uji hipotesis penelitian menggunakan paired t-test memberikan kesimpulan bahwa rata-rata skor post-test kemampuan berpikir kritis lebih besar dibandingkan rata-rata skor pretest pada saat penerapan pendekatan konflik kognitif di tiap kelas. $\mathrm{H}_{\mathrm{a}}$ diterima karena pada setiap kelas eksperimen diperoleh nilai sig. (2-tailed) $<0,05$, dan $\mathrm{H}_{\mathrm{o}}$ ditolak. Hasil ini sesuai dengan hasil penelitian Baser (2006) menyatakan bahwa pembelajaran dengan konflik kognitif dapat meningkatkan kemampuan berpikir kritis fisika peserta didik daripada menggunakan pembelajaran tradisional. Pembelajaran dengan konflik kognitif membuat peserta didik mengalami proses konflik atau konfrontasi konsep awal dengan konsep baru yang dipelajari (Wartono, Batlolona, \& Putirulan, 2018). Uji t berpasangan ini hanya memberikan kesimpulan bahwa rata-rata skor posttest lebih besar dibandingkan dengan skor 
pretest. Peningkatan hasil posttest ini secara lebih rinci dibahas pada uji $N$ - Gain yang dapat dilihat pada Tabel 2.

Tabel 2. Hasil N-Gain Kemampuan Berpikir Kritis

\begin{tabular}{cccccccc}
\hline \multirow{2}{*}{ Kelas } & \multicolumn{9}{c}{ N-Gain per Indikator Kemampuan } & \multirow{2}{*}{ N-Gain } & \multirow{2}{*}{ Kriteria } \\
& \multicolumn{9}{c}{ Berpikir Kritis } & & Total & \\
\cline { 2 - 5 } & $\mathrm{A}$ & $\mathrm{B}$ & $\mathrm{C}$ & $\mathrm{D}$ & $\mathrm{E}$ & & \\
\hline Eksperimen 1 & 67,53 & 61,46 & 44,00 & 55,45 & 39,39 & 53,57 & Sedang \\
Eksperimen 2 & 92,21 & 80,00 & 39,10 & 75,00 & 38,06 & 64,87 & Sedang \\
Eksperimen 3 & 86,49 & 58,43 & 37,90 & 62,50 & 35,88 & 56,24 & Sedang \\
\hline
\end{tabular}

Keterangan:

A: Menginterpretasikan; B: Menganalisis; C: Mengevaluasi; D: Menarik kesimpulan;

E: Penjelasan lanjut

$N$-Gain total untuk kemampuan berpikir kritis tergolong dalam kategori sedang pada setiap kelas eksperimen. Pendekatan konflik kognitif ini memberikan pengaruh yang hampir sama pada tiga kelas eksperimen dilihat pada setiap indikatornya. Peningkatan hasil kemampuan berpikir kritis umumnya terjadi pada peserta didik yang mengalami tingkat konflik kognitif yang tinggi pada saat pembelajaran. Berdasarkan hasil ini, maka dapat dikatakan penelitian ini berhasil sesuai dengan tujuan yang diharapkan. Keberhasilan penggunaan pendekatan konflik kognitif disebabkan karena dalam pembelajaran peserta didik mencari pengetahuannya sendiri, sehinggga akan membuat peserta didik lebih aktif dalam bekerja dan berpikir. Pengetahuan yang peserta didik dapatkan tidak bisa lepas dari pengetahuan yang telah didapatkan sebelumnya. Menjaga keterkaitan antara pengetahuan lama dengan pengetahuan yang akan diterima oleh peserta didik hingga membentuk pengetahuan baru sangatlah penting (Makhrus, Widodo, \& Agustini, 2018).

\section{KESIMPULAN}

Berdasarkan hasil dan pembahasan yang telah dipaparkan dapat disimpulkan bahwa pendekatan konflik kognitif dapat meningkatkan kemampuan berpikir kritis peserta didik pada saat proses pembelajaran dan berpengaruh signifikan terhadap kemampuan berpikir kritis pada materi gerak lurus. Hal ini menunjukan bahwa pendekatan konflik kognitif dapat dijadikan sebagai alternatif pendekatan/model/metode pada pembelajaran fisika.

\section{SARAN}

Pendekatan konflik kognitif dapat dijadikan alternatif pendekatan pembelajaran yang dapat diterapkan dalam mengajar fisika. Namun, dalam penerapannya memerlukan perencanaan dan persiapan yang matang sebelum diterapkan di kelas agar proses pembelajaran dapat berjalan sesuai dengan tujuan pembelajaran yang hendak dicapai. Sedangkan untuk penelitian selanjutnya, pendekatan konflik kognitif dapat dilakukan pada materi yang berbeda dengan subjek penelitian yang lebih luas.

\section{DAFTAR PUSTAKA}

Baser, M. (2006). Fostering Conceptual Change By Cognitive Conflict Based Instruction On Students' Understanding Of Heat And Temperature Concepts. Eurasia Journal of Mathematics, Science And Technology Education, 2(2), 96-114. 
Chow, T.-C. F., \& Treagust, D. F. (2013). An Intervention Study Using Cognitive Conflict to Foster Conceptual Change. Journal of Science and Mathematics Education in Southeast Asia, 36(1), 44-64.

Hidayatullah, Z., Jumadi, Nadhiroh, N., Kartika, E., Nuha, A. A., \& Erlangga, S. Y. (2020). Identifikasi Miskonsepsi Dan Konflik Kognitif Fisika: Kasus Terkait Perubahan Konseptual. EDUSAINS, 12(1), 64-71.

Hidayatullah, Z., Makhrus, M., \& Gunada, I. W. (2018). Analisis Tingkat Kemampuan Berpikir Kritis Gelombang Mekanik Melalui Pembelajaran Dengan Pendekatan Konflik Kognitif. Jurnal Pendidikan Fisika Dan Teknologi, 4(2), 151-157. https://doi.org/http://dx.doi.org/10.29303/jpft.v4i2.565

Lee, G., Kwon, J., Park, S. S., Kim, J. W., Kwon, H. G., \& Park, H. K. (2003). Development of an instrument for measuring cognitive conflict in secondary-level science classes. Journal of Research in Science Teaching, 40(6), 585-603. https://doi.org/10.1002/tea.10099

Makhrus, M. (2018). Peranan Konflik Kognitif Terhadap Perubahan Konseptual Pada Mahasiswa Tentang Konsep Gaya. Konstan - Jurnal Fisika Dan Pendidikan Fisika, 3(1), 1-8. https://doi.org/10.20414/konstan.v3i1.1

Makhrus, M., Widodo, W., \& Agustini, R. (2018). Efektifitas Model Pembelajaran CCMCCA Untuk Memfasilitasi Perubahan Konsep Gaya Pada Mahasiswa. Jurnal Pendidikan Fisika Dan Teknologi, 4(2), 253. https://doi.org/10.29303/jpft.v4i2.810

Makhrus, M., Zuhdi, M., Wahyudi, \& Taufik, M. (2020). Increasing Conceptual Understanding through CCM-CCA Based Learning Device. Jurnal Penelitian Pendidikan IPA, 6(1), 81-84. https://doi.org/10.29303/jppipa.v6i1.347

Nasution, S. W. R. (2018). Penerapan Model Inkuiri Terbimbing (Guided Inquiry) Dalam Meningkatkan Kemampuan Berpikir Kritis. Journal Education and Development, $3(1), 1-5$.

Priyadi, R., Mustajab, A., Tatsar, M. Z., \& Kusairi, S. (2018). Analisis Kemampuan Berpikir Kritis Siswa SMA Kelas X MIPA dalam Pembelajaran Fisika. Jurnal Pendidikan Fisika Tadulako Online (JPFT), 6(1), 53-55.

Setyowati, A., Subali, B., \& Mosik. (2011). Implementasi Pendekatan Konflik Kognitif Dalam Pembelajaran Fisika Untuk Menumbuhkan Kemampuan Berpikir Kritis Siswa Smp Kelas Viii. Jurnal Pendidikan Fisika Indonesia, 7(2), 89-96. https://doi.org/10.15294/jpfi.v7i2.1078

Sugiyono. 2017. Metode Penelitian Pendidikan: Pendekatan Kuantitatif, Kualitatif, Dan $R \& D$. Bandung: Alfabeta.

Usmeldi, Amini, R., \& Trisna, S. (2017). The Development Of Research-Based Learning Model With Science, Environment, Technology, And Society Approaches To Improve Critical Thinking Of Students. Jurnal Pendidikan IPA Indonesia, 6(2), 318325. https://doi.org/10.15294/jpii.v6i2.10680

Wartono, Batlolona, J. R., \& Putirulan, A. (2018). Cognitive Conflict Strategy and Simulation Practicum to Overcome Student Misconception on Light Topics. Journal of Education and Learning (EduLearn), 12(4), 747-756. https://doi.org/10.11591/edulearn.v12i4.10433

Wiradana, I. W. G. (2012). Pengaruh Strategi Konflik Kognitif dan Berpikir Kritis Terhadap Prestasi Belajar IPA Kelas VII SMP Negeri 1 Nusa Penida. Jurnal Pendidikan IPA, 2(2), 1-19. 